原著

Sjögren 症候群の剖検例

一一自験例ならびに日本病理剖検輯報に基づく 本邦における剖検の実態——

\author{
武田泰 典 ${ }^{1,3)}$ 尾 関 雅 彦1) \\ 小守昭2 石川梧 朗1
}

1) 東京医科歯科大学齿学部口腔病理学教室（主任：石川梧朗教授）

2) 徳島大学歯学部口腔病理学教室（主任：小守 昭教授）

3) 岩手医科大学歯学部口胫病理学講座（主任：鈴木鍾美教授）

（1980年 6 月 5 日 受付）

\title{
Autopsy Cases with Sjögren's Syndrome
}

- Report of Two Cases and a Review of the Cases in Japan-

\author{
Yasunori Takeda, ${ }^{1,3)}$ Masahiko Ozeki ${ }^{1}$, \\ Akira Komori ${ }^{2)}$ and Goro Ishikawa ${ }^{1)}$
}

1) Department of Oral Pathology, Faculty of Dentistry, Tokyo Medical and Dental University (Chief:: Prof. Goro Ishikawa)

2) Department of Oral Pathology, Faculty of Dentistry, Tokushima University (Chief: Prof. Akira Komori)

3) Department of Oral Pathology, Faculty of Dentistry, Iwate Medical College (Chief: Prof. Atsumi Suzuki)

Case 1 was 56-year-old female, who had been suffering fom Sjögren's syndrom ( $\mathrm{SjS}$ ) and primary biliary cirrhosis $(\mathrm{PBC})$ and was treated conservatively. Autopsy revealed characteristic findings of major salivary glands in SjS, terminal stage of $\mathrm{PBC}$ and widespread miliary tuberculosis. Case 2 was a 35 -year-old female, who had been suffering from SjS and SLE, and was received large dose of steroid drugs. Autopsy revealed marked atrophy of the salivary glands, diffuse lupus glomerulonephritis and systemic fungal infection.

Autopsy cases with SjS in Japan were reviewed from 1958 to 1978 which were published in the "Annual of the Pathological Autopsy Cases in Japan". There were 49 cases with SjS during this 21 years, being 44 female cases and 5 male cases. The mean age except 2 cases of suicide was 50.4 years. Collagen disease and/or autoimmune disease were found as a concomitance in many of the studied cases. The causes of death in cases with $\mathrm{SjS}$ were listed as systemic infection, respiratory disturbance, heart failure, liver dysfunction, etc. 


\section{緒}

Sjögren 症候群は唾液腺・涙腺を中心とした外 分泌腺の系統的な慢性進行性病変でありまた慢 性関節リウマチ1-4)，全身性エリテマトーデス5-9), 全身性硬化症 ${ }^{10-12)}$, 多発性筋炎 ${ }^{4,13)}$, 橋本病 $3,5,14$, 15)，自己免疫性肝炎 ${ }^{16,17)}$ あるいは原発性胆汁性肝 硬変症 ${ }^{18,19)}$ などの膠原病や他の自己免疫疾患を高 率に合併する。本症候群も自己免疫疾患の一つと 考光られるが, その多彩な臨床症状と検查成績か ら, 臓器特異的な面と非特異的な面をるった疾患 として位置づけられている20)。

Sjögren 症候群の詳細な病理解剖所見例は1943 年に Sjögren 自身が報告 ${ }^{21)}$ して以来, 諸家により 報告されているが，本邦では 1 例報告が散見され るのみで22-34)系統的な観察はみられない。以前に 筆者らは自験例より「Sjögren 症候群の 3 剖検 例」 ${ }^{35)}$ ， 日本病理剖検輯報（1958年より1975年ま で）より剖検例の実態を把握するために「日本に お汁る Sjögren症候群の剖検例」36) として報告を 行った。今回，新たに 2 剖検例を経験したのでそ の所見の概略を述べるとともに, 日本病理剖検輯 報より最近（1976年より1978年まで）の症例を追 加し, 過去21年間に拉ける本邦での Sjögren 症候 群剖検の実態を検索した。

\section{資料と方法}

自験例 2 例はいずれも東京医科歯科大学病理学 教室で剖検を行ったもの（症例 1：SN-5316, 症 例 $2: \mathrm{SN}-5402)$ で, 両症例とも生前に Sjögren 症候群の確定診断がなされていた。それぞれの臨 床経過は次項で述べる。

日本に扩活るSjögren 症候群の剖検例の調查資 料は日本病理学会編の日本病理剖検輯報で, 昭和 33 年度（同年 1 月 1 日より 12 月 31 日までの全国各 施設での剖検例を記載）の第 1 輯から第21輯（昭 和53年度）までの剖検輯報を調査した。この期間 の剖検例中, 臨床診断あるいは病理学的診断（主 病診断名末たは副病変）にSjögren 症候群として の記載のある症例を選出した。

\section{結果}

\section{Sjögren 症候群の 2 剖検例について}

症例 1 (剖検時56歳, 女性)

臨床経過：家族歷，既往歴に特記すべきことは ない。1966年より Raynaud 症状出現。1972年 夏, 全身倦急感, 黄㾝が出現し近医にて肝炎の診 断のもとに加療を受けた。1975年秋, 健診で蛋白 尿を指摘され，また体重減少がみられ，1976年某 病院受診, 再度黄疸を指摘され入院し, さらに東 京医科歯科大学第 1 内科に転科入院した。またこ のころより眼乾燥感に気付いている。入院時, 肝 脾腫，両側手指皮膚の著明な硬化，血清トランス アミラーゼ・血清ビリルビンの軽度上昇, 抗ミト コンドリア抗体・抗平滑筋抗体陽性, 血沈の䒕 進, 血清 Al-P • 血清 Ig-M の増加, 肝機能異常 などがみられた。検查所見より原発性胆汁性肝硬 変症 primary biliary cirrhosis (PBC) が疑われ た。開腹下肝生検では小葉間胆管の破壞, グリソ ン鞘の線維化と著明なリンパ性細胞浸潤がみられ (図 1)，PBC の確定診断がなされた。臨床所見 の詳細は宮坂らの報告37)を参照されたい。また眼 乾燥感, 唾液分泌低下などの諸症状より Sjögren 症候群が疑われた。耳下腺造影では典型的な apple-tree pattern を呈し，小唾液腺生検で著明 なリンパ性細胞浸潤と導管上皮の増殖がみられ (図 2)，Sjögren 症候群の確定診断がなされた。 一方，手指皮䖉生検で真皮抢よび皮下組織に膠原 線維の密な増生を及たが，他部の皮膚には著変な く, sclerodactylia そ診断された。入院後 6 力月 間の対症療法により諸症状は軽快した。その後外 来で follow-up されていたが，1978年初めより全 身状態が悪化，同年 7 月第 2 回目の入院をした。 入院時, 発熱, 腹水, 下肢浮腫, 黄疸がみられ, 検査成績は Alb. 2.5, T-P 7.1, GOT 165, GPT 52, LDH 218, Al-P 576, T-bil. 14.3 であった。 利尿剂，抗生剤の投与，中心静脈栄養がなされた が，体重減少が著しく $(1.5 \mathrm{~kg} /$ 週 $)$, 同年 8 月死 の転帰をとった。

剖検所見：剖桱は死後 9 時間で行った。全身の 


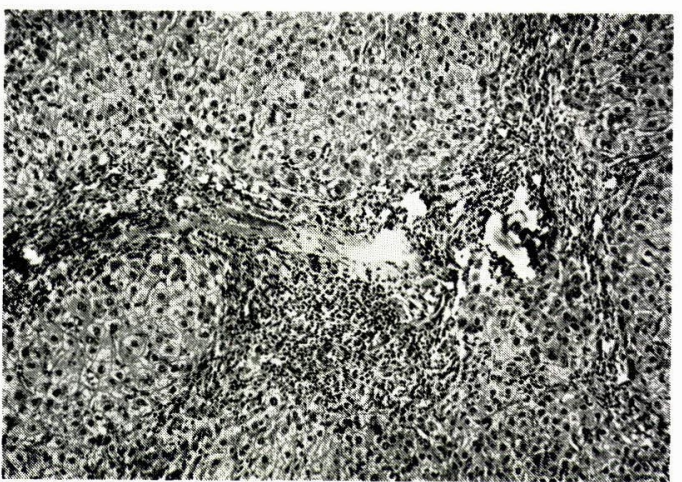

図 1 症例 1 開腹下肝生検組織像（死亡 1 年 10 力月前)。

小葉間胆管の破琉，グリソン鞘の線維化と

著明なリンパ性細胞浸潤をみる。

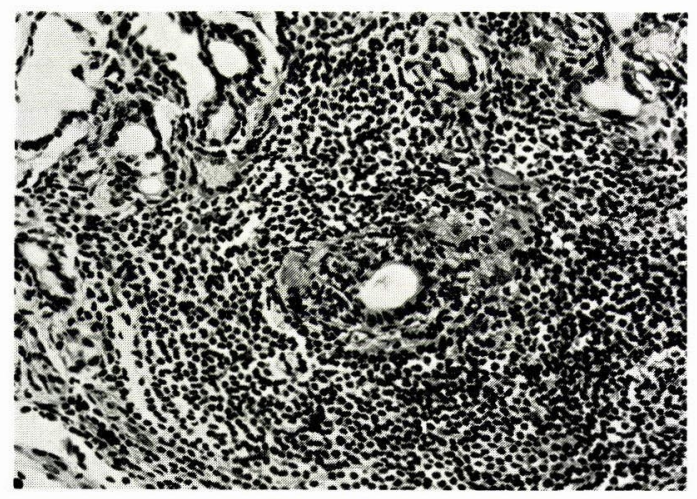

図 2 症例 1 口唇腺生検組織像（死亡 1 年 10 力 月前)。

著明なリンパ性細胞浸潤と導管上皮細胞の

增生がみられ，筇上皮帛様の所見を呈寸る。 $\times 120$ 。

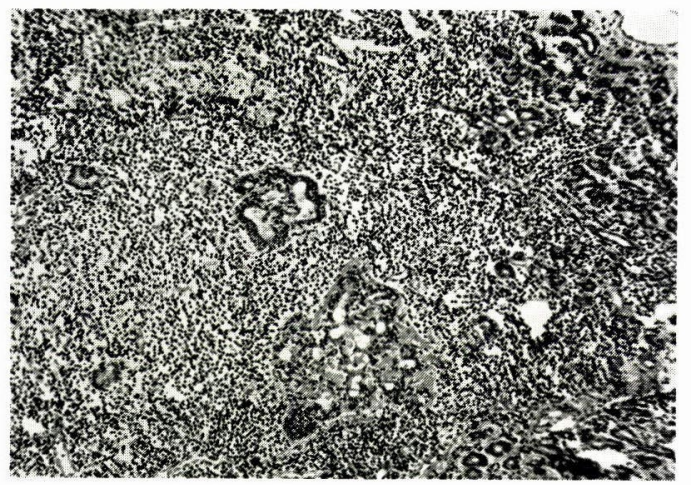

図 3 症例 1 耳下腺。唾液腺実質は浸潤細胞で 置換されている。筋上皮島が散在し，その内 外には硝子様物質为認められる。 $\times 120$

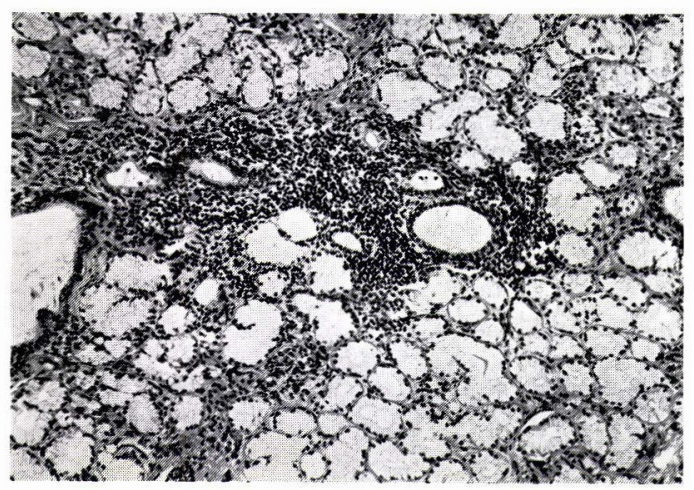

図 4 症例 1 口蓋腺。導管周囲性に限局性のリ ンパ性細胞浸潤をみる。 $\times 120$ 。

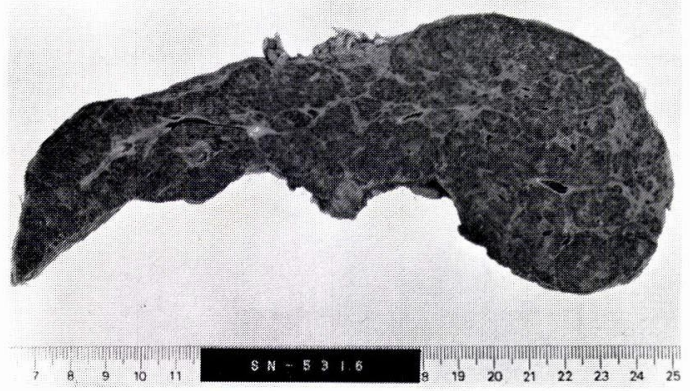

図 5 症例 1 肝割面。割面は菲薄な結合組織に 用まれた多数の小さな再生結節で占められて いる。

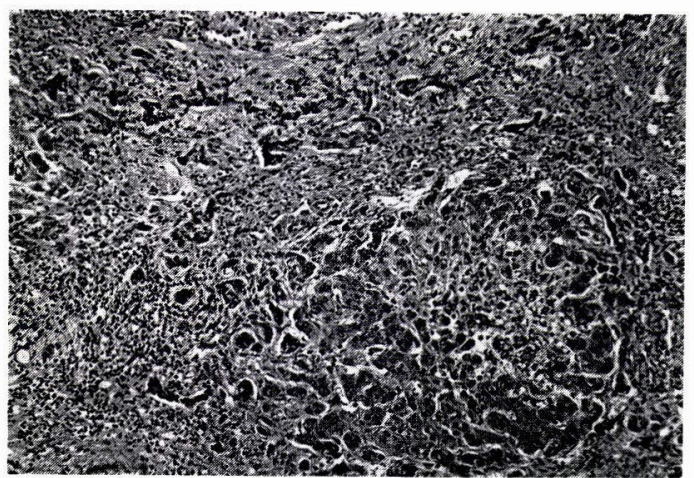

図 6 症例 1 肝再生結節。再生結節中央部は壊 死に陷っており, また, 周井線維化組織中に はリンパ性細胞浸潤が著明。×120。 


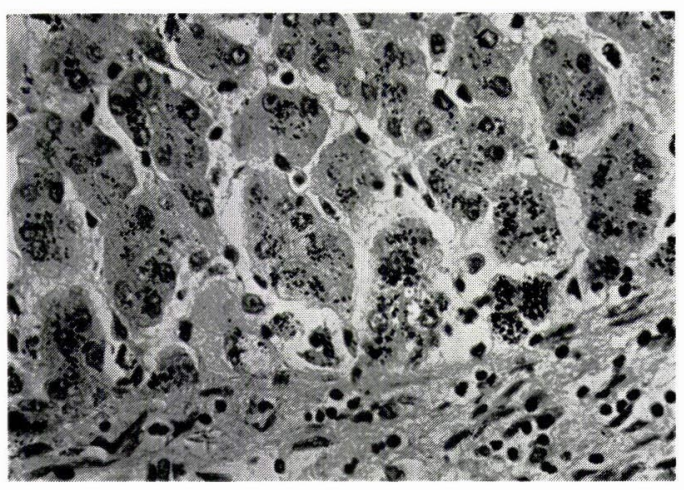

図 7 症例 1 肝再生結節辺縁部にみられた dimethylaminobenzylidenerhodanine 染色陽 性の肝細胞胞体内顆粒。 $\times 500$ 。

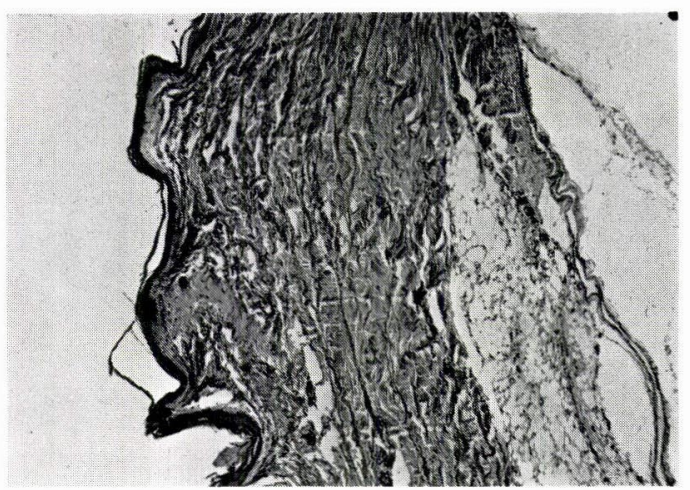

図 8 症例 1 手背皮䖉。真皮ならびに皮下組織 の膠原線維の著しい増生をみる。 $\times 50$ 。

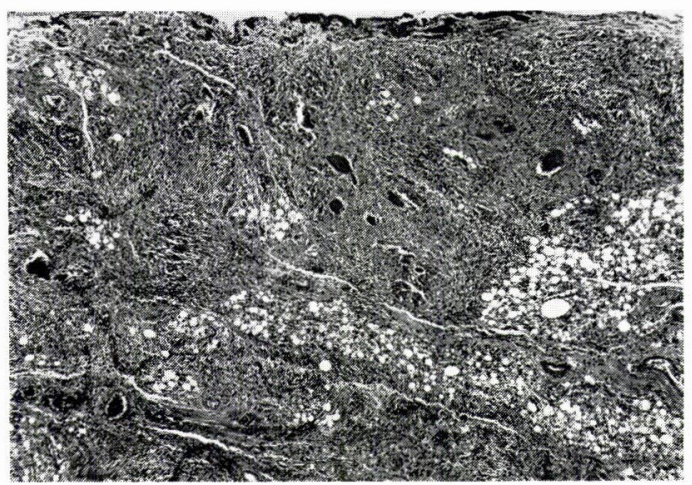

図 9 症例 1 全身諸蔵器に広沉にみられた結核 性病変。 $\times 50$ 。
るいそう（身長 $147 \mathrm{~cm}$, 体重 $28 \mathrm{~kg}$ ), 黄疸が著明 であり, 皮膚は乾燥, 皮下脂肪は著しく減少して いた。

大唾液腺, 涙腺は肉眼的にやや萎縮性であった が, 組織学的には著明なリンパ性細胞浸潤, 筋上 皮島の形成ならびに硝子様物質がみられ, 腺房細 胞の大部分は消失していた(図 3 )。小葉によって は線維化, 脂肪組織の増生を伴う萎縮性変化も著 明であった。小唾液腺には導管周囲性に中等度の 限局性リンパ性細胞浸潤がみられた(図 4)が，そ の程度は 1 年 10 月前の生検像に比べいくぶん軽 度であった。胃粘膜, 気管支腺, 膵臓へのリンパ 性細胞浸潤の程度は軽度であった。生前, 眼症状 が著明であったが, 角膜上皮には形態学的变化は なかった。

肝臓は $720 \mathrm{~g}$, 萎縮性で暗緑色, 表面細顆粒状 を呈し，割面は菲薄な結合組織に囲まれた無数の 小さな再生結節で占められていた(図 5 )。組織学 的には micronodular な再生結節が多数認められ (図 6 ), その中心部の細胞は, 脂肪変性, 壊死に陥 っており, 一方辺縁部の細胞には胆汁うっ滞が著 明であった。また辺縁部の細胞には Orcein 染色 陽性で, p-dimethylaminobenzylidenerhodanine 法で赤色を呈する微細顆粒がみられた（図 7 )。再 生結節周囲では線維化ならびにびまん性のリンパ 性細胞浸潤が顕著であった。以上の所見と臨床デ 一タより, PBC, Scheuerの分類で第 4 期（肝硬 変期）と診断した。これに関連して胸水(左1,000 $\mathrm{ml}$, 右 $1,000 \mathrm{ml})$, 食道静脈瘤, 胆汁性ネフロー ゼ (左 $110 \mathrm{~g}$, 右 $130 \mathrm{~g}$ ), 軽度の脾腫をみた。

手指の皮膚硬化のあった部位は上皮基底細胞層 のメラニン色素の増加, 真皮ならびに皮下組織の 密な膠原線維の増生, 汗腺の萎縮が著明であった (図 8)。しかし，毛細血管の拡張や皮下組織の石 灰化像はみられず，また他部位の皮膚にも著変は なかった。生前になされた食道機能検査などにも 異常がなかったことから, 本病变は限局性のもの と考光 sclerodactylia と診断した。

両肺 (左 $360 \mathrm{~g}$, 右 $220 \mathrm{~g}$ ), 胸膜, 腹膜, 各り ン, 節, 肝臓, 腎臓, 脾臓の各臟器に広汎に拡が 
った粟粒結核を認め(図 9)，PBC とともに直接 死因となったものと考えた。

副所見として, 心蔵 $(240 \mathrm{~g})$ の褐色萎縮, 左卵 巣囊胞, 副腎 (左 $2.5 \mathrm{~g}$, 右 $3.5 \mathrm{~g}$ ) ・ 甲状腺の萎 縮があった。脳 $(1,320 \mathrm{~g})$, 下垂体には著変は認 めなかった。

病理診断：
A) Sjögren 症候群
B）原発性胆汁性肝硬変症（肝硬変期）
C) Sclerodactylia
D）広汎な栗粒結核症（両肺，胸膜，腹膜，全 身のリンパ節, 朋, 脾, 両腎)

※直接死因：原発性胆汁性肝硬変症（肝硬変 期）による肝不全ならびに広汎な粟粒結核 症。

症例 2（剖検時35歳，女性）

臨床経過 : 既往歴として腎孟腎炎 (20歳時) が ある。家族歴に特記すべさことはない。1966年よ り肘, 膝, 足趾の関節痛出現。1969年第 1 子死産 ( 9 力月) 後より発熱, リンパ節腫脹が出現し, 近医で膠原病の疑いとされていた。1971年より Raynaud 症状が出現，また眼・腔の乾燥症状 も自覚するようになり，翌年精查のため東京医科 歯科大学第 1 内科㳊 1 回目の入院をした。入院 時, 血清 $\gamma-\mathrm{G}$ の高值, 抗核抗体陽性, RA 因子陽 性, Waaler-Rose 1：64, 耳下腺造影で appletree pattern, 小唾液腺生検では著明なリンバ性 細胞浸潤と導管上皮の增生がみられた（図10）。 以上の所見より Sjögren 症候群と確定診断され た。以降，ステロイド剤の投与がなされていた が，るいそうが著明となり $(28 \mathrm{~kg}) ， 1973$ 年第 2 回目の入院。1974年11月, 早期破水による出産直 後より高血圧, 全身の浮腫のため第 3 回目の入 院。検查所見では血沈の亢進, 蛋白尿, 血清アル ブミンの低下などがみられ, 腎生検の結果 lupus nephritis と診断され(図11), ステロイド剂の増量 投与がなされた。1979年初めより労作時の息切れ がみられ，近医で肺炎と診断されたが精查のため 第 4 回目の入院をした。腎機能は Cr. 71, BUN 94 で腎不全状態にあり, lupus nephritis の急性増

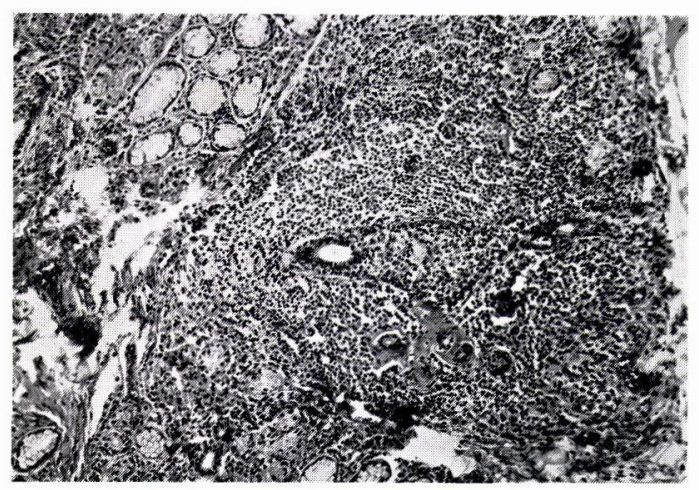

园10 症例 2 口唇腺生検組織像（死亡 6 年 5 力 月前)。

小葉全体にわたるリンパ性細胞浸潤と著明 な導管上皮の増生をみる。 $\times 120$ 。

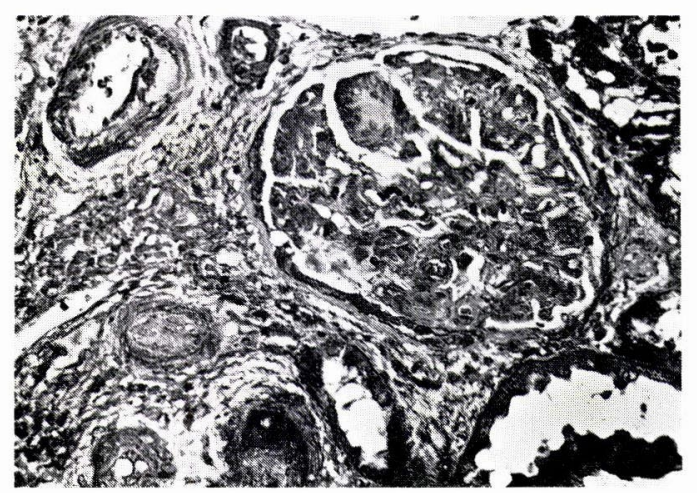

図11 症例 2 腎生検組織像(死亡 4 年 4 力月前)。 腎系球体係蹄基底膜の肥厚がみられる。 $\times 300$ 。

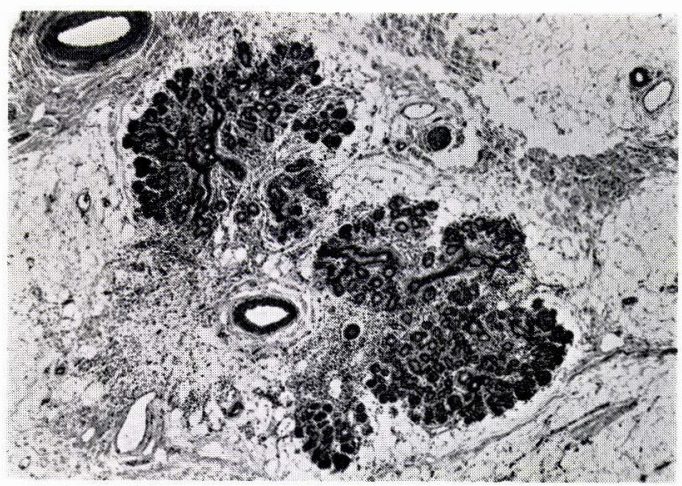

図12 症例 2 耳下腺。脂肪組織の増生を伴ら萎 縮性変化が著明であり，腺実質はいわゆる tubular metaplasia あるいは canalicular regression の所見を呈する。リンパ性細胞浸 潤は高度ではないが全体にびまん性にみられ る。 $\times 50$ 。 


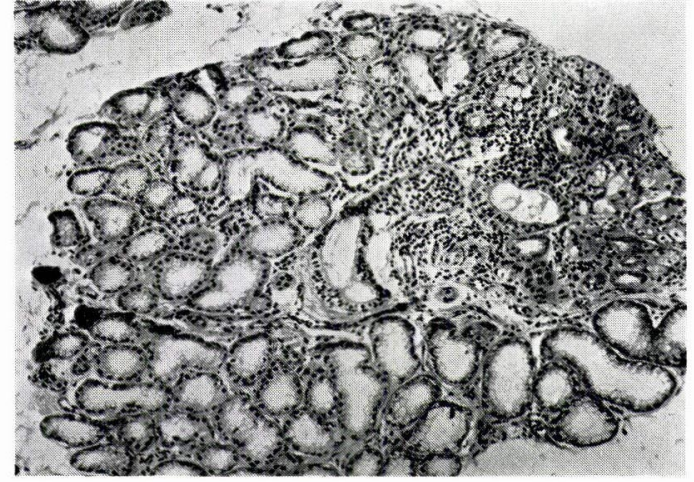

図13 症例 2 口唇腺。一部に軽度のリンパ性細 胞浸潤を㝊る。 $\times 120$ 。

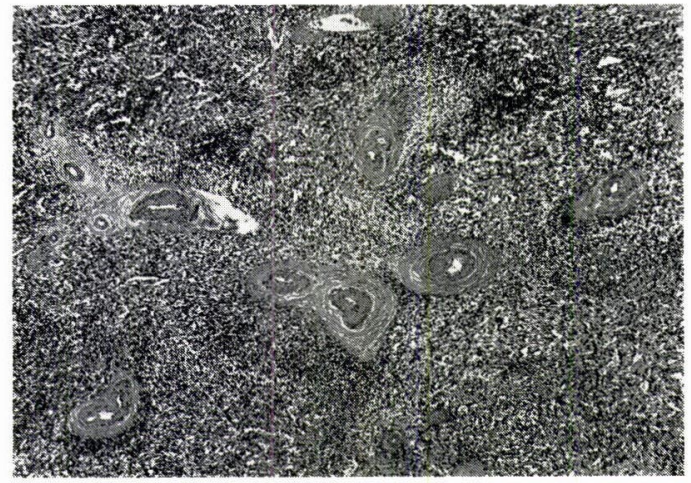

困16 症例 2 脾蔵の onion-skin lesion。 $\times 50$ 。

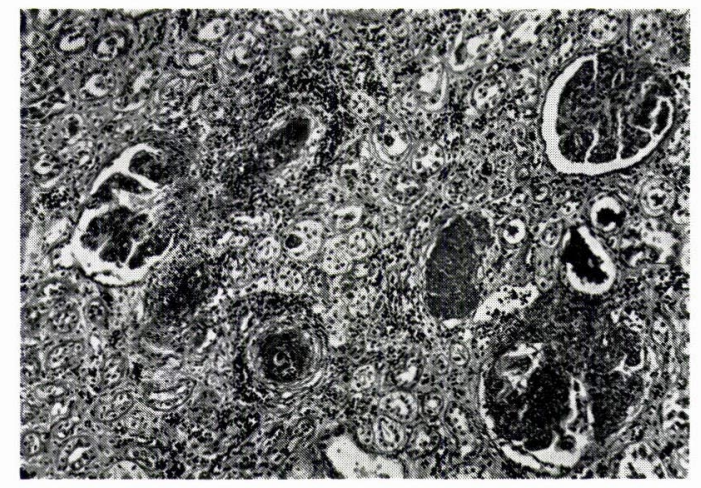

図14 症例 2 腎。系球体基底膜の肥厚, 細胞成 分の増加, 細血管のフィブリノイド壞死, 間 質の線維化とリンハ性細胞浸潤をみる。 $\times 120$ 。

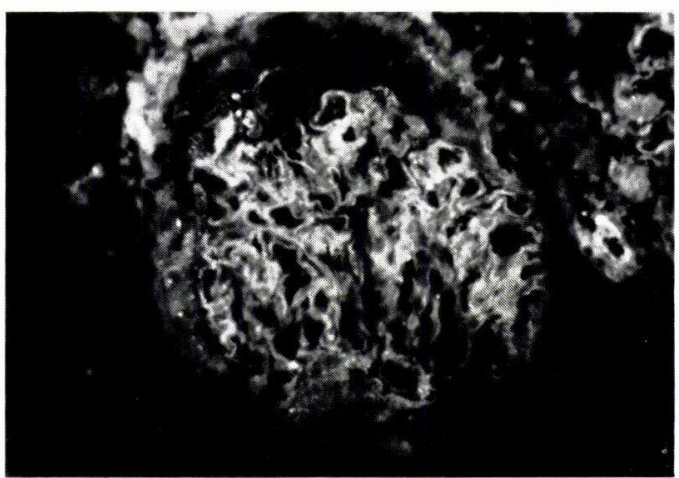

図15 症例 2 腎系球体基底膜の螢光抗体法所 見。 Ig-G に陽性で linear pattern を示す。

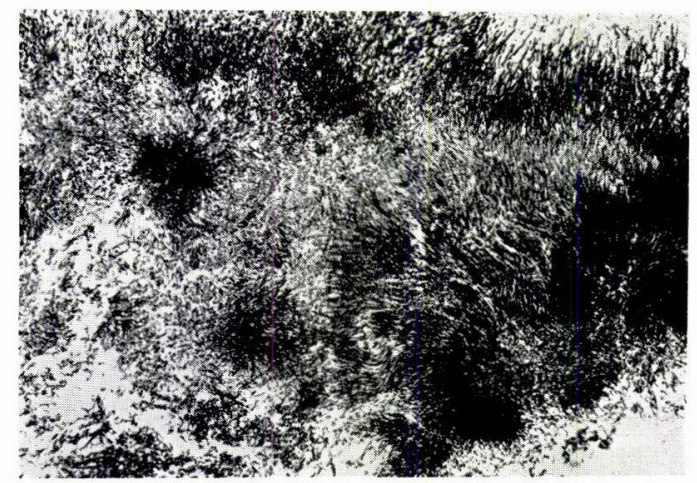

図17 全身諸臓器に広沉に認められた真菌 (candida ならびに aspergillus)。PAS, $\times 60$ 。

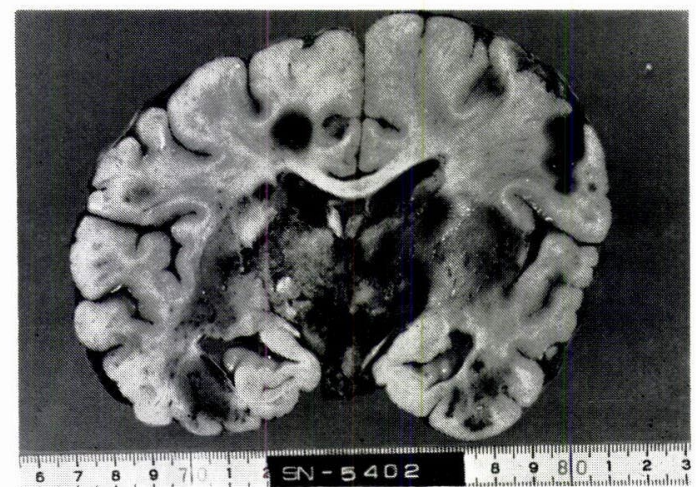

図18 症例 2 大脳割面。基底核を中心とする広 沉な軟化壊死巣をみる。 
悪と考えられた。腹膜灌流，ステロイド剤の増量 ならびにパルス療法などがなされたが腎不全症状 は改善せず, 更に肺炎様症状, 発熱, 出血傾向, 意識障害がみられるようになり，同年 4 月，死の 転帰をとった。

剖検所見：剖検は死後 5 時間で行った。体格は 中等度 (身長 $145 \mathrm{~cm}$, 体重 $42 \mathrm{~kg}$ ) であり, 満月様 顔貌を呈していた。

大唾液腺は萎縮が著明であり, 組織学的にも脂 肪組織の増生と腺房の消失が顕著であった。一部 に残存する腺実質はいわゆる tubular metaplasia あるいは canalicular regression とよばれる所見 を呈し，同時にびまん性のリンパ性細胞浸潤がみ られた(図12)。小唾液腺では導管周囲性に軽度か ら中等度のリンパ性細胞浸潤がみられたが，腺実 質は保たれていた(図13)。涙腺は線維化が進行し 腺房の萎縮・消失が著明であり，同時にびまん性 のリンパ性細胞浸潤がみられた。本症例では乳腺 にもびまん性のリンパ性細胞浸潤を認めた。

腎臓（左 $130 \mathrm{~g}$ ，右 $120 \mathrm{~g}$ ）は被膜剝離しがた く, 表面細顆粒状, 皮質は萎縮性で, 皮髄境界は 不明瞭であった。組織学的には糸球体のメサンギ ウム細胞は増生し, 基底膜は肥厚する傾向にあっ た(図14)が，典型的な wire-loop lesion の所見は みられなかった。これら肥厚した糸球体基底膜は 䖝光抗体直接法で抗ヒト Ig-G に陽性であった （図15）。間質には線維化と高度のリンパ性細胞浸 潤がみられた。また細血管の fibrinoid necrosis が著明であり(図14)，その領域組織は境界明瞭な 壞死巣となっていた。脾蔵は $200 \mathrm{~g}$ と腫大し, onion-skin lesion が散在していた(図16)。膵臓の 小動脈の一部には fibrin 血栓がみられた。

両肺(左690g, 右920 g ), 胸膜, 脳 $(1,420 \mathrm{~g}$ ), 腹膜, 心臓 $(290 \mathrm{~g})$, 胃, 肝蔵 $(1,280 \mathrm{~g})$, 臎臓, 甲状腺, 骨髅の各臓器には candida ならびに aspergillus の感染がみられた（図17）。これら真菌 の感染は脳と肺に顕著であり, 脳の広沉な軟化 （図18）と肺膿瘍が直接死因と考えられた。胸水 (左 $200 \mathrm{ml}$, 右 $300 \mathrm{ml}$ ) 獚色混濁, 腹水 $(200 \mathrm{ml})$ は血性であった。
副所見として胃の多発性潰瘍，びまん性の甲状 腺腫，鎖骨上窩リンパ節と肺門リンパ節の腫大， 骨髄の顆粒球系の増加がみられた。下垂体，大動 脈, 生殖器系, 胆道系には著変なかった。

病理診断 :
A) Sjögren 症候群
B） SLE ならびにループス腎炎
C）広汎な真菌症（脳, 両肺, 胸膜, 心, 胃, 肝, 腹膜, 膵, 甲状腺, 骨䯣)

※直接死因：広沉な真菌症（とくに脳，両 肺）ならびに腎の多発性限局性壊死による 腎不全。

\section{2. 日本病理剖検輯報に基づく本邦における Sjögren 症候群剖検例について}

1958年から1978年までの過去21年間に日本病理 剖検輯報に記載されている全国各施設での剖検総 数は416, 718例であり, らち Sjögren 症候群例は 49例であった(表 1 )。年度別にみると Sjögren 症

表 1 日本病理剖検輯報による各年度の剖検体総数 ならびそ Sjögren 症候群の剖検数

（1958～1978年）

\begin{tabular}{|c|c|c|c|}
\hline 年 & 度 & 剖検総数 & Sjögren 症候群例 \\
\hline & 1958 & 9,297 cases & 0 cases \\
\hline & 1959 & 10,059 & 0 \\
\hline & 1960 & 11,115 & 1 \\
\hline & 1961 & 13,276 & 0 \\
\hline & 1962 & 15,041 & 0 \\
\hline & 1963 & 16,350 & 0 \\
\hline & 1964 & 19,464 & 0 \\
\hline & 1965 & 19,476 & 0 \\
\hline & 1966 & 19,020 & 0 \\
\hline 10. & 1967 & 20,902 & 0 \\
\hline 11. & 1968 & 25,224 & 0 \\
\hline 12. & 1969 & 23,914 & 3 \\
\hline 13. & 1970 & 22,003 & 2 \\
\hline 14 & 1971 & 22,050 & 4 \\
\hline 15 & 1972 & 22,717 & 4 \\
\hline 16. & 1973 & 23,275 & 3 \\
\hline 17. & 1974 & 23,163 & 2 \\
\hline 18 & 1975 & 23,018 & 3 \\
\hline 19 & 1976 & 24,259 & 12 \\
\hline 20 & 1977 & 25,997 & 8 \\
\hline 21. & 1978 & 30,098 & 7 \\
\hline & Total & 416,718 & 49 \\
\hline
\end{tabular}


表 2 Sjögren 症候群剖検例の性別・年歯別分布

\begin{tabular}{cccc}
\hline Age & Male & Female & Total \\
\hline $20-29$ & 2 & 2 & 4 \\
$30-39$ & & 6 & 6 \\
$40-49$ & & 13 & 13 \\
$50-59$ & 1 & 13 & 14 \\
$60-69$ & 1 & 8 & 9 \\
$70-79$ & 1 & 2 & 3 \\
\hline Total & 5 & 44 & 49
\end{tabular}

候群例は主として1969年度以降にみられ，特に 1976年度以降に多い。

Sjögren 症候群剖検例の性別・年齢別分布は表 2 に示すごとくである。すなわち性別では女性例 44 例 $(89.9 \%)$ ，男性例 5 例 $(10.1 \%)$ ，年齢別で は40歳代と50歳代が最も多く，平均年秢50.4歳で あった。

42例の臨床診断名は表 3 のごとく，1．Sjögren 症候群のみと記載されたもの 23 例, 2 . 自殺例 2 例,
3. 他合併疾患と併記されたもの10例，4. Sjögren 症候群の病名が臨床診断名に記載されていないも の14例であった。この14例はいずれも病理学的診 断名に Sjögren 症候群の病名が記載されており, これらの半数例以上は臨床診断名として他の自己 免疫疾患あるいは膠原病が記載されていた。

49例の病理学的主診断名は表 4 のごとく，1. Sjögren 症候群のみのもの15例，2. 他の合併疾患 と併記されていたもののらちSjögren 症候群の診 断名が最初に記載されていたもの11例，3. 他疾患 の次に Sjögren 症候群の病名が記載されていたも の14例, 4. 主診断名に Sjögren 症候群以外の他疾 患名のみが記載されていたもの 9 例であった。こ の 9 例のらち, 副所見に Sjögren 症候群の記載が あったもの 3 例， Sjögren 症候群の疑いと記載さ れていたもの 1 例, 慢性唾液腺炎と記載されてい たもの 1 例，唾液腺萎縮と記載されていたものが 1 例であった。

病理学的主診断名にSjögren 症候群の記載のあ

表 3 Sjögren 症候群 $(\mathrm{SjS})$ 剖検例の臨床診断名

1. $\mathrm{SjS}(23$ cases $)$

2. $\mathrm{SjS}+$ Suicide ( 2 cases)

3. Others $+\mathrm{SjS}$ (10 cases)

Scleroderma ( 2 cases), Liver cirrhosis ( 2 cases), RA, Primary biliary cirrhosis, Tbc, Cerebral bleeding, Uterine Ca., Salmonellosis

4. Others (14 cases)

RA ( 2 cases), PSS (2 cases), RA + Pneumonia, SLE+RA + Pneumonia, SLE + Dermatomyositis, Hypergammaglobulinemia, Acute hepatitis, Sarcoidosis, Acute heart failure+SLE, Liver cirrhosis, Gastric Ca., Cachexia, Sialadenitis

表 4 Sjögren 症候群 $(\mathrm{SjS})$ 剖検例の病理学的主診断名

1. $\mathrm{SjS}$ (15 cases)

2. $\mathrm{SjS}+$ Others $(11$ cases $)$

Suicide (2 cases), Hashimoto's thyroiditis + Liver cirrhosis, RA, SLE + Cerebral bleeding,

Chronic glomerulonephritis, DM, Tbc, Myocardial infarction, Aortic stenosis, Bronchopneumonia

3. Others + SjS (14 cases)

Cerebral bleeding ( 2 cases), Gastric Ca. (2 cases), PBC, PSS, SLE+Pulmonary fibrosis, RA+Amyloidosis,

Scleroderma, RA+Glomerulonephritis + Interstitial pneumonia,

SLE + Dermatomyositis + Chronic hepatitis, Tbc, Chronic hepatitis, Cervical Ca.

4. Others (9 cases)

PSS, Necrotic demyelinating encephalitis, Panperitonitis, Liver cirrhosis + Acute pancreatic necrosis, Tbc, Pulmonary hypertension, Ileo-cecal multiple ulceration, Thyroid Ca.+Nephrosclerosis + Renal calculus, Malignant lymphoma + Pulmonary Ca.+Gastric Ca. 
表 5 Sjögren 症候群剖検例の副病変（数字は延べ数）

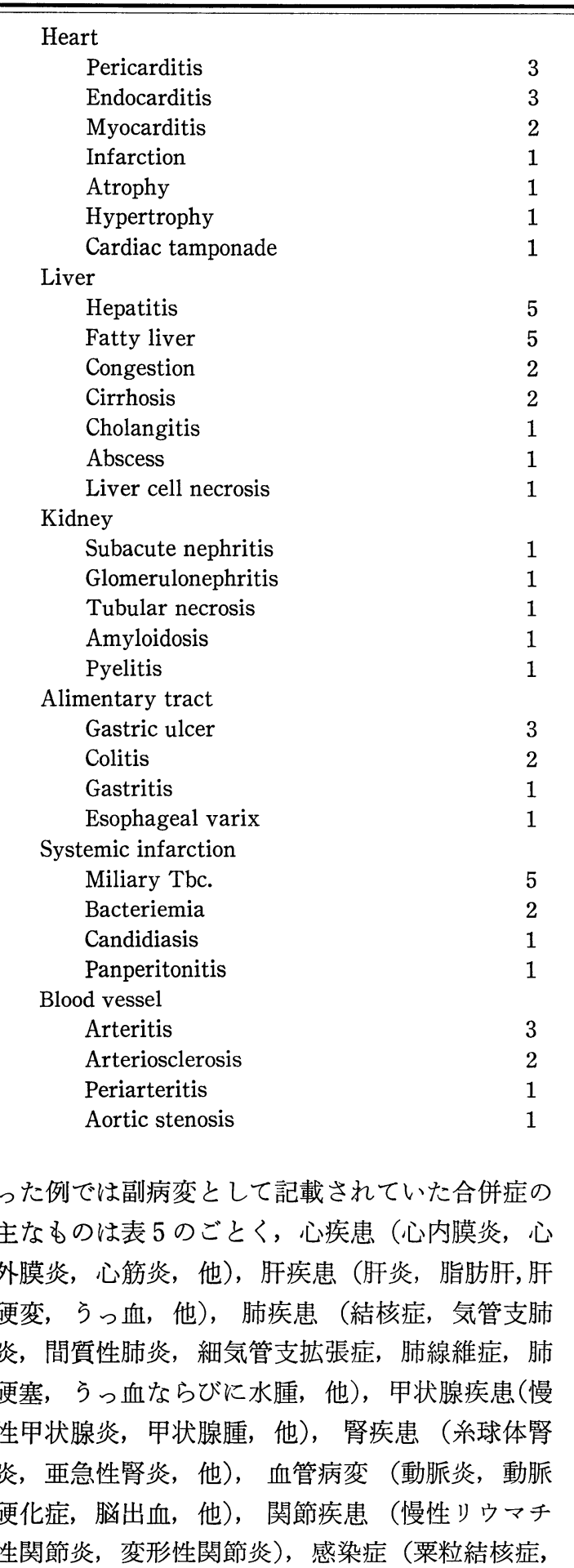

Lung

$\begin{array}{ll}\text { Tuberculosis } & 3 \\ \text { Bronchopneumonia } & 3 \\ \text { Interstitial pneumonia } & 2 \\ \text { Bronchioectasis } & 2 \\ \text { Pulmonary infarction } & 2 \\ \text { Pulmonary fibrosis } & 2 \\ \text { Congestion and edema } & 2 \\ \text { Hyaline-membranosis } & 1 \\ \text { Atelectasis } & 1 \\ \text { Pulmonary hypertension } & 1 \\ \text { Pneumothorax } & 1\end{array}$

Thyroid gland

Chronic thyroiditis 3

Goitor $\quad 3$

Atrophy 1

Joint

RA 1

Arthritis deformans 1

Neoplasm

Cervical Ca. 1

Pseudolymphoma 1

Myoma uteri 1

Others

Adrenal adenoma 1

Amyloidosis (systemic) 2

Splenomegalia 2

Ascites 2

Pleural effusion $\quad 1$

Splenitis 1

Cholecystitis 1

Anemia 1

Cystitis 1

表 6 Sjögren 症候群剖検例の直接死因と考えられ る病変

$\begin{array}{lc}\text { Systemic infection } & 12 \text { cases } \\ \text { Respiratory disturbance } & 8 \\ \text { Heart failure } & 5 \\ \text { Renal failure } & 5 \\ \text { Hepatic insufficiency } & 4 \\ \text { Cerebral bleeding } & 2 \\ \text { Malignant neoplasm } & 1 \\ \text { DIC } & 1 \\ \text { Unknown } & 9 \\ \text { (Suicide } & 2 \text { ) }\end{array}$


真菌症, 敗血症, 他), 全身性アミロイド症など であった。また 1 例で pseudolymphoma の記載 があった。

Sjögren 症候群に拈ける死因は表 6 のごとく, 感染症, 呼吸不全, 心不全, 肝不全, 腎不全が主 なものであった。

\section{考察}

Sjögren 症候群は1933年, Sjögren が 角膜・ 結膜の乾燥 keratoconjunctivitis sicca， 口腔の 乾燥 xerostomia 拈よび多発性関節炎を伴う病態

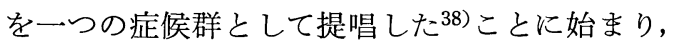
当初リウマチ性関節炎の一亜系之も考兄られてい た。近年, 本症候群患者に高頻度に各種膠原病・ 自己免疫疾患の合併がみられること，多彩な自己 特異抗体が検出されること, 細胞性免疫の低下が みられることなどから，自己免疫疾患の一つとし て注目されている。Sjögren 症候群の病理解剖例 の詳細は1943年に Sjögren 自身により報告21)さ れている。本邦では1960年に稲葉・山崎により 最初の剖検例が発表22)され，その後も 1 例報告は 散見される23-37)が，未だ症例の系統的な検索は十 分とはいえない。今回, 筆者らは新たに本症候群 の 2 剖検例を経験したのでその所見の概略を述べ るとともに，日本病理剖検輯報をもとに過去 21 年 間に技ける本邦でのS Sjögren 症候群剖検例の実態 を検索した。

自験例 2 例はいずれも Sjögren 症候群に他の自 己免疫疾患を合併し，感染症で死亡した症例であ る。症例 1 は Raynaud 症状, 黄疸で発症し, 経 過中に乾燥症状も出現し, $\mathrm{PBC}+$ Sjögren 症候群 の確定診断がなされていた ( $\mathrm{PBC}$ の初期像は肝硬 変ではないため本来は“PBC”といら名称は不適 当と考光られ，Rubin らにより “chronic nonsuppurative destructive cholangitis” といら名 称が疾患の本質をよく示すものとして提唱されて (る) ${ }^{18)}$ 。Sjögren 症候群と PBC の合併例につい て, Shearn ${ }^{39)}$ は80名の Sjögren 症候群例を詳細 に検討した結果 5 名に PBC もしくは慢性肝炎の 病像を認めたと報告している。一方，PBC の側
から Sjögren 症候群との合併例を検索した報告で は, Rubin 5 ${ }^{18)}$ は PBC 63例中 Sjögren 症候群 1 例 (1.6\%), Sherlock と Sheuer ${ }^{19)}$ は PBC 100例 中Sjögren 症候群 3 例（3\%） と報告している。

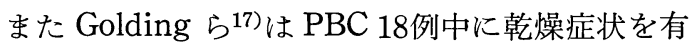
するものが13例（72\%）であったと述べている。 各報告者において Sjögren 症候群ならびに PBC の診断基準が統一されていたわけでなく，また合 併症例についても Sjögren 症候群を主体に考学る もの，PBCを主体に考えるものなど，データと しては必ずしも一致したものとはいえない。しか し，従来よりSjögren 症候群にはしばしば肝機能 障害を伴らことが知られている。現在, Sjögren 症候群の疾患概念として, 本症候群は単なる唾液 腺・涙腺の病変ではなく広く外分泌腺全体に及ぶ 病変と考兄られ，とくに導管上皮系が問題とされ ている。肝内胆管は外分泌腺ではないが外分泌腺 と同様に体外へ通ずる導管の一部であり, 解剖 学的には外分泌腺導管と相同するものである。 Sjögren症候群に和ける肝機能障害あるいはPBC の合併は, 以上のような導管上皮系に対する共通 抗原の存在を示唆するのかもしれない。事実, 唾 液腺導管, 肝内胆管さらには腎尿細管に存在する 共通抗原を求めようとする試みがなされ40-42), 唾 液中の蛋白に対する抗血清が正常の胆管上皮細胞 と特異的に反応したことが報告されている42)。今 後さらに病因解明の意味からもこのような症例が 集積され，系統的な検索がなされねばならない。

症例 2 は最初に Sjögren 症候群の確定診断がな され, さらに妊娠・出産を契機として SLE へ進 展した症例である。しかし，このよらな合併例に 拈いて, 膠原病あるいは自己免疫疾患症例の大部 分の患者がそらであるように, 真の発症時点と, いずれが先行したのかは明確には判定しがたい。 Sjögren 症候群には種々の膠原病や自己免疫疾患 が高頻度に合併することは周知のごとくである が, 本症候群とSLE との合併頻度はリウマチ性関 節炎に次いでおり，5１2\%と報告されている7 39,43-45)。一方, SLE の側からみた Sjögren 症候群 の合併頻度は30４0\% と報告されている ${ }^{8,9)}$ 。さら 
に Grennan ら ${ }^{9}$ は臨床的に乾燥症状のないSLE 患者の $65 \%$ に耳腺造影あるいは口唇腺生検で Sjögren 症候群に和けると同様の变化をみたこと

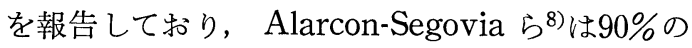
SLE 患者に同様の所見をみたと述べている。ま た，本邦でも岡辺ら ${ }^{46)}$ は臨床的に乾燥症状のなか った13例の SLE 剖検例の大唾液腺ならびに小唾 液腺を詳細に検索した結果, 定形的なSjögren 症 候群の組織像よりやや軽微だが，大部分の症例で リンパ性細胞浸潤と導管上皮の増生性变化を認め たと報告している。SLE をはじめ他の全身性自 己免疫疾患に打けるこれら唾液腺の変化 ${ }^{47-49)}$ は非 臓器特異的自己免疫疾患としての一所見なのか, あるいはいわゆる subclinical な Sjögren 症候群 の合併と考えるのかは現在のところ決めがたく， 今後さらに各方面からの詳細な検索が望まれる。

本邦に和いて従来 Sjögren 症候群は比較的稀な 疾患と考兄られていた。しかし, 本症候群は唾液 腺・沪腺をはじめとする全身の外分泌腺を標的と した蔵器特異的な面と, 多彩な自己抗体が出現 乙，かつ他の自己免疫疾患を高頻度に合併する非 臓器特異的な面をもった疾患として各方面からの 関心を集めるとともに症例数も次第に増えつつあ る。現在日本に打ける推定患者総数は 20,000 人之 報告されている50)。しかし，剖検例についての本 症候群の系統的な報告は未だ内外でみられない。 今回の過去21年間の日本病理剖検輯報に基づく調 査では, 記載されている剖検総数 416, 718 例中, Sjögren 症候群例は49例であり，とくに1976年以 降の例が半数以上を占めていた。一般に Sjögren 症候群の年齢分布は40～50歳といわれ，診断時の 平均年齢は $42 \sim 48$ 歳と報告されている ${ }^{4,39,51)}$ 。今 回の調査での剖検時平均年齢は 2 例の自殺例をの ぞいて50.4歳であり, 慢性の経過をとる疾患の割 には診断時平均年齢との差はほとんどない。本検 索で対象とした症例は種々の合併症により死亡し ているため, これら合併症を伴いやすい例は経過 が短いとも考兄られるが，さらに個々の症例の詳 細な解析や合併症のない症例の経過との比較検討 などがなされねばならない。
Sjögren 症候群の剖検例を通覧すると主病変は 1）唾液腺・涙腺を中心とした外分泌腺の病变と 2）合併症による病変の 2 つ分けられる。唾液 腺・沪腺を中心とした外分泌腺の病変の程度は剖 検輯報の記載のみからでは明らかではない。合併 症としてはやはり膠原病あるいは自己免疫疾患に 属するものが比較的多い傾向にあった。また臓器 別には肝疾患, 肺疾患, 心疾患, 腎疾患, 血管病 変が多かった。直接死因としては免疫能の低下に よると考兄られる全身性の感染症が全体の $1 / 4$ を しめており, 次いで呼吸障害, 心不全, 肝障害, 腎不全などの合併症であった。したがって本症候 群患者の予後は合併症により左右されるといって も過言ではなく、データの積み重ねが望まれる が，病理剖検輯報自体がきわめて簡単な記載なた め, 今後各症例の詳細な検索が必要と考学る。

自己免疫疾患に伴う悪性腫瘍の発生はよく知ら れており ${ }^{52)}$, 臓器特異的な疾患は, 例えば慢性甲 状腺炎に括ける甲状腺癌, 悪性貧血に打ける胃癌 などのようにその標的臟器の悪性腫瘍の合併が特 徵的である。これに対し全身性の免疫不全症にお ける合併悪性腫瘍の $80 \%$ はリンパ系腫瘍であるこ とが欧米では注目されている52)。Sjögren 症候群 においても malignant lymphoma の合併するこ とが Talal ら ${ }^{53)}$ とよ注目されて以来, 欧米で は本症候群の経過中に malignant lymphoma や macroglobulin 血症の発症をみた症例が多数報告 されている54-60)。また malignant lymphoma の 側からみると, 他の悪性腫瘍に比べ膠原病や自己 免疫性溶血性貧血の合併が有意に高いことが確か められている61)。しかし, 本邦では Sjögren 症候群 と malignant lymphoma の合併例の報告は1968 年に吉永により生検例の 1 例が報告されているだ け62)であり，この症例についてもその後の経過な ぞについて追加報告はなされていない。過去21年 間に打けるSjögren 症候群剖検例49例中の 1 例に 病理学的主診断名に悪性リンパ腫, 他の 1 例に 副所見に pseudolymphoma の記載がみられた。 Malignant lymphoma と Sjögren 症候群の合併 例は日本ではきわめて稀なものか否か, 今後各方 
面からの検索を期待したい。

\section{結 論}

1. Sjögren 症候群の最近の 2 自験剖検例の剖 検所見の概略を述べるとともに，本邦の剖検例に 怙けるSjögren 症候群の実態を検索するために過 去21年間の日本病理剖検輯報を調查した。

2. 自験例 2 例はいずれも他の自己免疫疾患 （原発性胆汁性肝硬变症ならびに SLE）を合併し ており長期の経過をとったもので, 剖検により広 汎な感染症がみられた。これら 2 例の Sjögren 症 候群とそれぞれの合併疾患との関連性についても 考察を加えた。

3. 過去21年間の日本病理剖検輯報に記載され ている剖検体の総数は 416,718 例であり，うち Sjögren 症候群例は49例であった。年齢別には40 歳代と50歳代に最も多く，女性例が89.8\%であっ た。合併症としては膠原病または自己免疫疾患と 考兄られる病変の記載が多く，また直接死因とし ては全身性の感染症, 呼吸器疾患, 心疾患, 肝疾 患などであった。

本研究は厚生省特定疾患シェーグレン病調査研究 班の補助による。な技, 要旨の一部は第69回日本病 理学会総会(昭和55年 6 月・札幌)において発表した。

\section{文献}

1) Gifford, S. R., et al.: Keratoconjunctivitis sicca. Arch. Ophthal., 30: 207-216, 1943.

2) Henderson, J. W.: Keratoconjunctivitis sicca. Amer. J. Ophthal., 33: 197-223, 1950.

3) Vanslow, N. A., et al.: A clinical study of Sjögren's syndrome. Ann. Intern. Med., 58: 124135, 1963.

4) Bloch, K. J., et al.: Sjögren's syndrome. Medicine, 44: 187-231, 1965.

5) Heaton, J. M.: Sjögren's syndrome and systemic lupus erythematosus. Brit. Med. J., 1: 446469, 1959.

6) Bain, G. O.: The pathology of Mikulicz-Sjögren's disease in relation to disseminated lupus erythematosus. Canad. Med. Assoc. J., 82: 143148, 1960.

7) Steinberg, A. D. and Talal, N.: The coexistence of Sjögren's syndrome and systemic lupus ery- thematosus. Ann. Intern. Med., 74: 55-61, 1971.

8) Alarcon-Segovia, D., et al.: Sjögren's syndrome in systemic lupus erythematosus. Ann. Intern. Med., 81: 577-583, 1974.

9) Grennan, D. M., et al.: Sjögren's syndrome in SLE, Part 1. Nz med J, 86: 374-376, 1977.

10) Shearn, M.A. : Sjögren's syndrome in association with scleroderma. Ann. Intern. Med., 52: 1352-1362, 1960.

11) Alarcon-Segovia, D., et al.: Sjögren's syndrome in progressive systemic sclerosis. Am. J. Med., 57: 78-85, 1974.

12) Cipoletti, J. F., et al.: Sjögren's syndrome in progressive systemic sclerosis. Ann. Intern. Med., 87: 535-541, 1977.

13) Silberberg, D. H.: Late-life myopathy occurring with Sjögren's syndrome. Arch. Neurol., 6: 428-438, 1962.

14) Stoltze, C. A., et al.: Keratoconjunctivitis sicca and Sjögren's syndrome. Arch. Intern. Med., 106: 513-522, 1960.

15）斎藤慎太郎, 他: Sjögren 症候群と甲状腺疾 患. 内科, 22(7) : 1580-1584, 1968.

16) Whaley, K., et al.: Liver disease in Sjögren's syndrome and rheumatoid arthritis. Lancet, 1: 861-864, 1970.

17) Golding, P.L., et al.: Sicca complex in liver disease. Br. Med. J., 4(7): 304-342, 1970.

18) Rubin, E., et al.: Primary biliary cirrhosis. Chronic non-suppurative destructive cholan gitis. Am. J. Pathol., 46: 387-407, 1965.

19) Shirlock, S. and Sheuer, P. J.: The presentation and diagnosis of 100 patients with primary biliary cirrhosis. N. Engl. J. Med., 289: 674679, 1973.

20) Raitt, I. M.: Essential immunology, 3 ed., Blackwell scientific pablications, Oxford, London, Edinburgh, Melbourne. 1977, pp. 265-301.

21) Sjögren, H.: A new conception of keratoconjunctivitis sicca. Aust. Med. Pub. Co., Sydney, 1943.

22）稲葉鐘吾, 山崎啓二 : Sjögren 症候群の 1 剖検 例. 日皮会誌，70(7)：722，1960.

23）高沢 博, 他: Sjögren 症候群を呈した 1 剖検 例. 唾液腺シンポジウム, $8: 11,1967$.

24）金子哲也，他：Sjögren 症候群の 1 剖検例. 臨 床免疫, 1 : 補冊 $39,2,1969$.

25）国定岑生, 他：Sjögren 症候群の 1 剖検例. 臨 床病理, 18(11) : 823-824, 1970.

26）明田昌三, 他 : Sjögren 症候群の 1 剖検例. 三 重医学, $14: 257-262,1970$.

27）山際裕司, 他: Sjögren 症候群の 1 剖検例. 内 
科, $27(1): 189-194,1971$.

28）加藤義一，他 : Sjögren 症候群の 1 剖検例. 日 内会誌, $60(7): 673,1971$.

29）萩原正雄, 他 : Sjögren syndrome $の 1$ 剖検例. 日本臨床, 32(7) : 171-175, 1974.

30）杉本浩一, 他: Sjögren 症候群の 1 剖検例. 日 本眼科紀要, 26(4) : 345-351， 1975.

31）有川 卓，他：心筋硬塞で死亡した Sjögren 症 候群を伴う甲状腺機能低下症．医のあゆみ，92 (11) : 493-502, 1975.

32）岡田憲彦，他：肝硬変症を伴った Sjögren 症候 群の 1 剖検例. 日病会誌, $64: 104,1975$.

33）山根一秀, 他 : 著しい黄疸（原発性胆汁性肝硬 変症）を主徵として発症した Sjögren 症候群の 1 剖検例. 臨床免疫, 8(2): 261-267, 1976.

34）岡田 淳, 有輪六朗：腎不全を示した Sjögren 症候群の 1 剖検例. 日病会誌, $66: 335,1977$.

35）石川梧朗, 他 : Sjögren 症候群の 3 剖検例. 厚 生省特定疾患シェーグレン病調查研究班昭和 51 年度研究業績, 1977, pp. 92-98.

36）石川梧朗, 他：日本に打けるシェーグレン症候 群の剖検例. 厚生省特定疾患シェーグレン病調 查研究班昭和52年度研究業績, 1978, pp. 43-50.

37）宮坂信之, 他：シェーグレン症候群, Sclerodactylia を合併した原発性胆汁性肝硬变症の 1 例. 日消化器誌, 74(10) : 1392-1397, 1977.

38) Sjögren, H.: Zur Kenntnis der Keratoconjunctivitis sicca (Keratitis filiformis bei Hypofunktion der Tränendrüsen). Acta Ophthal. (Kbh), 11: 1-151, 1933.

39) Shearn, M. A.: Sjögren's syndrome. W. B. Saunders Co., Philadelphia, 1971.

40) Smith, M. G. M., et al.: Cell-mediated immune responses in chronic liver disease. Br. Med. J., 1: 527-530, 1972.

41) Tsantoulas, D. C., et al.: Cell-mediated immunity to human Tamm-Horsfall glycoprotein in autoimmune liver disease with renal tubular acidosis. Br. Med. J., 4: 491-494, 1974.

42) McFarlane, I. G., et al.: Cellular immune responses to salivary antigen in autoimmune liver disease with sicca syndrome. Clin. Exp. Immunol., 25: 389-395, 1971.

43）鈴木輝彦 : 臨床免疫学叢書4., 免疫学からみた 消化管疾患, 医学書院, 東京, 1974, pp. 223246.

44）浅川英男 : Overlap 症候群としての Sjögren 症 候群. 日本臨床, 34(6) : 35-40, 1976.

45) 大藤 真, 宮脇昌二 : シェーグレン症候群. リ ウマチ, 19(3) : 269-276, 1979.

46）岡辺治男, 他：紅斑性狼瘡に括ける唾液腺病変 について. 口科誌, 23(2) : 299-300, 1974.

47) Whaley, K., et al.: Lymphocytic sialadenitis in the buccal micosa in Sjögren's disease, rheumatoid arthritis and arthritides. Acta Rheum. Scand., 14: 298-308. 1968.

48) Eisenbud, L., et al.: Palatal biopsy as a diagnostic aid in the study of connective tissue disease. Oral Surg., 35(5): 642-648, 1973.

49) Friedman, H., et al.: Lip biopsy in connective tissue disease. Oral Surg., 47 (3): 256-262, 1979.

50）東條 毅, 他：シェーグレン病の疫学調查. 厚 生省特定疾患シェーグレン病調査研究班昭和 54 年度総会記録.

51）浅川英男：内科シリーズ「自己免疫病のすべ て」, 南江堂, 東京・京都, 1973, pp.158-172.

52) Melief, C. J. and Schwartz, R. S.: Immunocompetence and malignancy. Cancer: A comprehensive treatise, Vol. 1, Edited by F. F. Becker, New York, Plenum Press, 1975, pp. 121-159.

53) Talal, N. and Bunim, J. J.: The development of malignant lymphoma in the course of Sjögren's syndrome. Am. J. Med., 36: 529-540, 1964.

54) Hornbarker, J. H., et al.: Sjögren's syndrome and nodular reticulum cell sarcoma. Arch. Intern. Med., 118: 449-452, 1966.

55) Talal, N., et al.: Extrasalivary lymphoid abnormalities in Sjögren's syndrome (reticulum cell sarcoma, "pseudolymphoma", macroglobulinenia). Am. J. Med., 43: 50-64, 1967.

56) Bark, C. J. and Porzik, S. L.: Mikulicz's disease, sialoangiectasis and autoimmunity based upon a study of parotid lesion. Am. J. Clin. Path., 49: 683-689, 1968.

57) Pinkus, S. G. and Dekker, A.: Benign lymphoepi thelial lesion of the parotid glands associated with reticulum cell sarcoma. Cancer, 25(1): 121-127, 1970.

58) Anderson, I. and Talal, N.: The spectrum of benign to malignant lymphoproliferation in Sjögren's syndrome. Clin. Exp. Immunol., 10: 199-221, 1971.

59) Faguet, G. B., et al.: Immunologically diagnosed malignancy in Sjögren's pseudolymphoma. Am. J. Med., 65: 424-429, 1978.

60) Whitehouse, A. C., et al.: Macroglobulinemia and vasculitis in Sjögren's syndrome. Experimental observation relating to pathogenesis. Am. J. Med., 43: 609-619, 1976.

61) Miller, D. G.: The association of immune disease and malignant lymphoma. Ann. Intern. Med., 66: 507-521, 1976.

62）吉永徹夫 : 悪性腫瘍を合併した Sjögren 症候群 の 2 例. 日本臨床, $26: 2161-2165,1968$. 